\title{
Studies on the Wear Behaviour of High Chromium Alloy Steels
}

\author{
Marius Valeriu COMICI \\ Transilvania University of Brasov, Romania, comici.valeriu.marius@unitbv.ro \\ Ioan GIACOMELLI \\ Technical Sciences Academy of Romania, Transilvania University of Brasov, giacomelli@unitbv.ro \\ Maria STOICANESCU \\ Transilvania University of Brasov, Romania, stoican.m@unitbv.ro
}

\begin{abstract}
There was studied a steel highly alloyed with chromium, with an average carbon content. The research aimed to highlight the influences of various heat and thermochemical treatment operations on the wear resistance. $40 \mathrm{Cr} 130$ has multiple uses in practice, and in many of them the products are subject to intense mechanical stress and wear. There were performed quenching operations followed by tempering at several temperature and time variants. Ionic nitriding operations were also performed. On samples of the given steel, the wear resistance was determined using the Pin-on-disk method, highlighted by the dynamic friction coefficient $\mu$ and the wear coefficient K.
\end{abstract}

Keywords

chromium alloy steels, wear behaviour

\section{Introduction}

The mechanical stress of metallic parts affects the entire volume of the material (traction, compression, bending, fatigue, etc.); in addition to these inherent stresses occurred during operation, the corrosion, erosion and abrasion stresses must also be considered.

The wear of surface layers can be caused by abrasion, cutting or scratching caused by high hardness abrasive particles that penetrate between the contact surfaces; furthermore, the wear occurs at the area of contact between two metallic surfaces in reciprocal movement; wear can also occur in cold conditions, as well as due to the heating caused by friction.

The wear resistance of a material increases with the decrease of the amount of material removed from the surface under certain stress conditions. The material can be removed during the experimental test by rubbing, rolling, scratching.

Wear resistance can be assessed using several indicative factors, including:

- wear volumetric intensity:

where

$$
\mathrm{IV}=\Delta \mathrm{V} / \mathrm{Lf} \quad\left[\mathrm{mm}^{3} / \mathrm{km}\right]
$$

$\Delta \mathrm{V}$ - volume of material lost due to wear [ $\left.\mathrm{mm}^{3}\right]$;

Lf - friction length [km];

- wear gravimetric intensity:

$$
\operatorname{Ig}=\Delta \mathrm{m} / \mathrm{Lf} \quad[\mathrm{g} / \mathrm{km}]
$$

where

$\Delta \mathrm{m}$ - mass of material lost due to wear [g];

- dynamic wear coefficient:

where

$$
\mathrm{K}=\Delta \mathrm{V} / \mathrm{N} \cdot \mathrm{Lf} \quad\left[\mathrm{mm}^{3} / \mathrm{N} \cdot \mathrm{m}\right]
$$

$\mathrm{N}$ - normal pressing force [N];

- average wear rate:

$$
\mathrm{Vu}=\Delta \mathrm{V} / \mathrm{t} \quad\left[\mathrm{mm}^{3} / \mathrm{min}\right]
$$


where

$\mathrm{t}$ - wear test time [min].

This indicator allows the determination of both the wear behaviour and of the dynamic friction coefficients $(\mu)$.

\section{Experimental Tests}

The studied steel (40Cr130) has the chemical composition presented in Table 1.

Table 1. Chemical composition of 40Cr130

\begin{tabular}{|l|l|l|c|c|c|c|c|c|c|c|}
\hline \multicolumn{2}{|l|}{ Steel grade } & \multicolumn{1}{|c|}{ Chemical composition [\%] } \\
\hline $\begin{array}{l}\text { Numerical } \\
\text { symbol }\end{array}$ & $\begin{array}{l}\text { Alphanumerical } \\
\text { symbol }\end{array}$ & STAS 3583 & $\mathrm{C}$ & $\mathrm{Cr}$ & $\begin{array}{c}\mathrm{Mn} \\
\max \end{array}$ & $\begin{array}{c}\mathrm{Si} \\
\max \end{array}$ & $\begin{array}{c}\mathrm{P} \\
\max \end{array}$ & $\begin{array}{c}\mathrm{S} \\
\max \end{array}$ & $\begin{array}{c}\text { Mo } \\
\max \end{array}$ & $\begin{array}{c}\mathrm{Cu} \\
\max \end{array}$ \\
\hline 1.4031 & X39Cr13 & $40 \mathrm{Cr} 130$ & $0.35-$ & $\begin{array}{c}12.5- \\
0.42\end{array}$ & 1.0 & 1.0 & 0.045 & 0.03 & 0.2 & 0.3 \\
\hline
\end{tabular}

Samples of this material underwent multiple heat and thermochemical treatment operations. The heat treatments were performed by heating in vacuum ovens and cooling in ventilated nitrogen. The thermochemical treatment consisted of plasma nitriding. Table 2 describes these technological operations.

Table 2. Heat and thermochemical treatments applied to 40Cr130

\begin{tabular}{|c|c|c|c|c|c|}
\hline \multirow{2}{*}{$\begin{array}{c}\text { Annealing } \\
{\left[{ }^{\circ} \mathrm{C}\right]}\end{array}$} & \multirow{2}{*}{$\begin{array}{c}\text { Quenching } \\
{\left[{ }^{\circ} \mathrm{C}\right]}\end{array}$} & \multirow{2}{*}{$\begin{array}{c}\text { Tempering } \\
{\left[{ }^{\circ} \mathrm{C}\right]}\end{array}$} & \multirow{2}{*}{$\begin{array}{c}\text { Ionic } \\
\text { nitriding }\end{array}$} & \multicolumn{2}{|c|}{ Hardness } \\
\hline & & & & Core [HRC] & Layer [HV] \\
\hline \multirow[t]{6}{*}{770} & \multirow[t]{2}{*}{950} & 150 & \multirow{2}{*}{$520^{\circ} \mathrm{C}, 20 \mathrm{~h}$} & 51.5 & 575 \\
\hline & & 510 & & 52.8 & 544 \\
\hline & \multirow[t]{2}{*}{1040} & 150 & \multirow[t]{2}{*}{$520^{\circ} \mathrm{C}, 20 \mathrm{~h}$} & 54.0 & 588 \\
\hline & & 510 & & 52.9 & 584 \\
\hline & \multirow[t]{2}{*}{1100} & 150 & \multirow[t]{2}{*}{$520^{\circ} \mathrm{C}, 20 \mathrm{~h}$} & 50.8 & 558 \\
\hline & & 510 & & 51.6 & 538 \\
\hline
\end{tabular}

The figures $1 \ldots 4$ show images of the structures of the samples $(\varnothing 20 \times 15 \mathrm{~mm})$ treated according to Table 2.

For the correct determination of the measurement results, the surfaces intended for wear tests have been properly finished. The test was performed using a Pin-on-disk tribometer, assisted by an electromagnetic transducer (LVDT - Linear Variable Differential Transformer - sensor), and a Taylor Thomson profilometer. This system allows the determination of the friction coefficients and of the wear rate based on the volume of material lost.

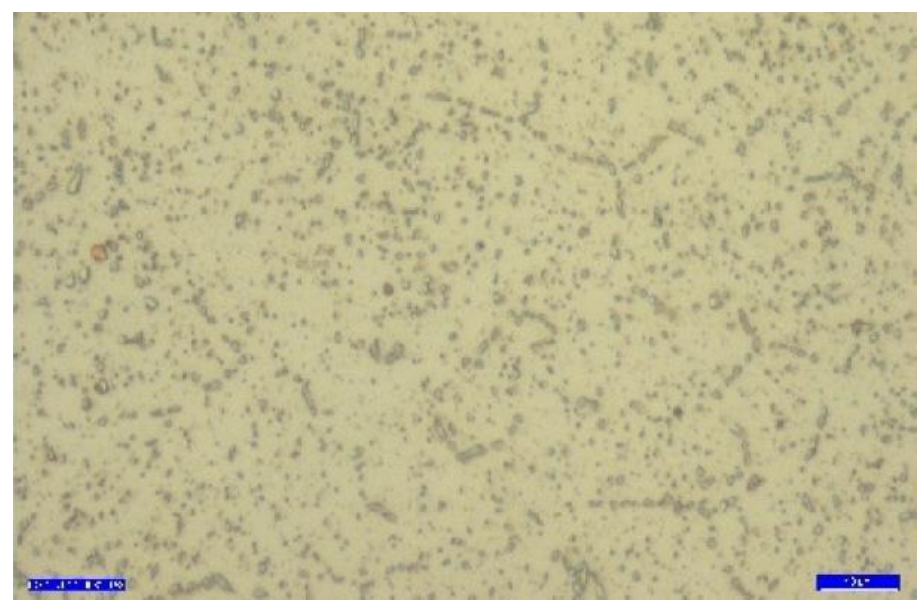

Fig. 1. $40 \mathrm{Cr} 130$, annealed at $770{ }^{\circ} \mathrm{C}$ and cooled in air. Scale $1000: 1$ 


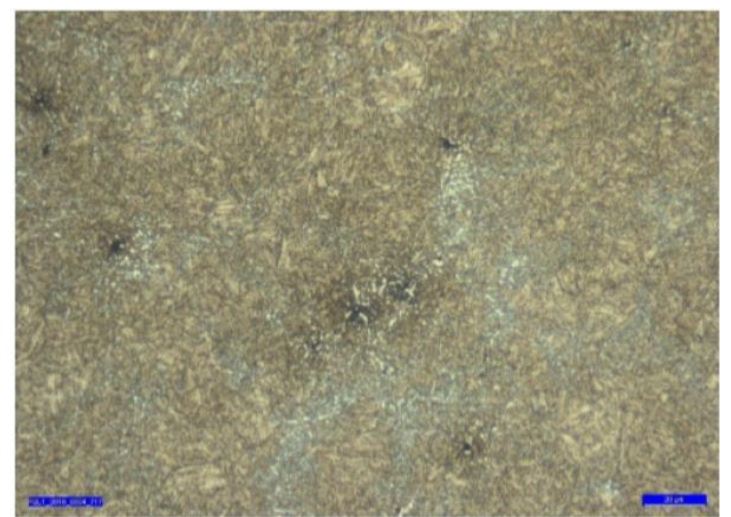

Fig. 2. $40 \mathrm{Cr} 130$, vacuum quenched from $1040{ }^{\circ} \mathrm{C}$, cooled in nitrogen and tempered at $150{ }^{\circ} \mathrm{C}$. Scale 1000:1

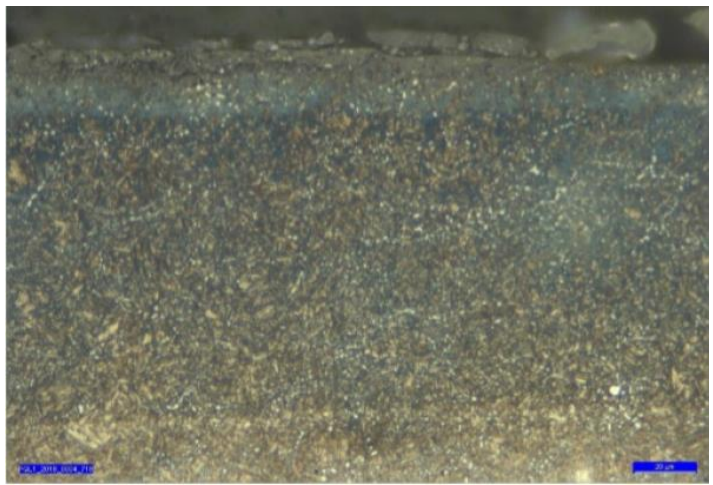

Fig. 3. $40 \mathrm{Cr} 130$, quenched in vacuum from $1040{ }^{\circ} \mathrm{C}$, tempered at $150{ }^{\circ} \mathrm{C}$ and nitrided at $520^{\circ} \mathrm{C}$. Scale 1000:1

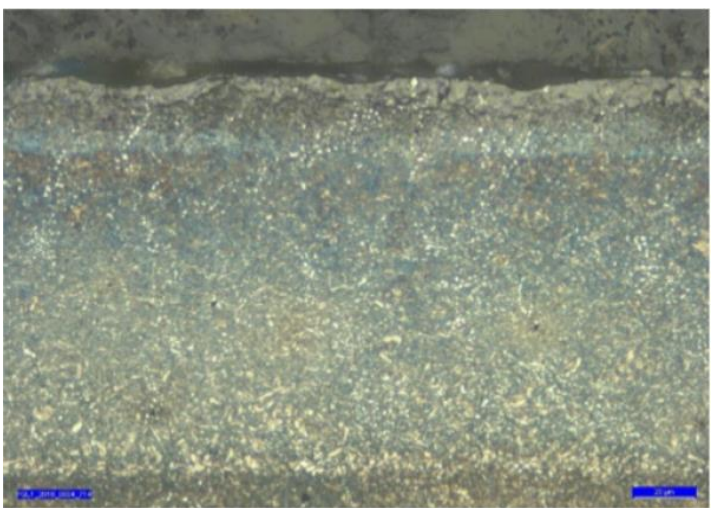

Fig. 4. $40 \mathrm{Cr} 130$, quenched in vacuum from $1040{ }^{\circ} \mathrm{C}$, tempered at $510{ }^{\circ} \mathrm{C}$ and nitrided at $520^{\circ} \mathrm{C}$. Scale 1000:1

The test conditions were the same for all samples, i.e.:

- Wear trace radius $5 \mathrm{~mm}$;

- Normal load applied $10 \mathrm{~N}$;

- Maximum number of rotations 400;

- Ambient temperature $24^{\circ} \mathrm{C}$;

- Humidity $32 \%$.

The average wear rate is calculated according to the volume of material lost during the test. This volume is determined based on the section of the wear trace, provided by the Taylor - Thomson profilometer.

The determinations carried out on samples treated differently led to the results presented in Table 3 . 
RECENT, Vol. 22, no. 2(64), 2021

Table 3. Coefficients $\mathrm{K}$ and $\mu$ for $40 \mathrm{Cr} 130$

\begin{tabular}{|c|c|c|c|c|c|}
\hline \multirow{2}{*}{\multicolumn{2}{|c|}{ Heat treatment }} & \multirow{2}{*}{\multicolumn{2}{|c|}{$\begin{array}{c}\text { Thermochemical treatment } \\
\text { Ionic nitriding }\end{array}$}} & \multirow{3}{*}{$\begin{array}{c}\text { Wear } \\
\text { coefficient K } \\
{\left[\mathrm{mm}^{3} / \mathrm{Nm}\right]}\end{array}$} & \multirow{3}{*}{$\begin{array}{l}\text { Dynamic friction } \\
\text { coefficient } \mu\end{array}$} \\
\hline & & & & & \\
\hline $\begin{array}{c}\text { Quenching } \\
{\left[{ }^{\circ} \mathrm{C}\right]}\end{array}$ & $\begin{array}{c}\text { Tempering } \\
{\left[{ }^{\circ} \mathrm{C}\right]}\end{array}$ & $\begin{array}{c}\text { Temperature } \\
{\left[{ }^{\circ} \mathrm{C}\right]} \\
\end{array}$ & $\begin{array}{c}\text { Time } \\
{[\mathrm{h}]}\end{array}$ & & \\
\hline \multirow{2}{*}{1040} & 150 & - & - & 8.8 & 0.66 \\
\hline & 510 & - & - & 10.2 & 0.79 \\
\hline \multirow{2}{*}{950} & 150 & 520 & 20 & 3.7 & 0.57 \\
\hline & 510 & 520 & 20 & 9.5 & 0.52 \\
\hline \multirow{2}{*}{1040} & 150 & 520 & 20 & 7.0 & 0.6 \\
\hline & 510 & 520 & 20 & 5.2 & 0.52 \\
\hline \multirow{2}{*}{1100} & 150 & 520 & 20 & 5.8 & 0.56 \\
\hline & 510 & 520 & 20 & 4.8 & 0.52 \\
\hline \multirow{2}{*}{770} & \multirow{2}{*}{1040} & 150 & \multirow{2}{*}{-} & 57.2 & - \\
\hline & & 510 & & 53.1 & - \\
\hline
\end{tabular}

The system used in the tests allows obtaining charts of the variation of the dynamic friction coefficient during the wear process. The average values of the dynamic friction coefficients are determined based on this, according to the data in Table 3.

Figures 5 and 6 show the sets of charts for two of the cases.
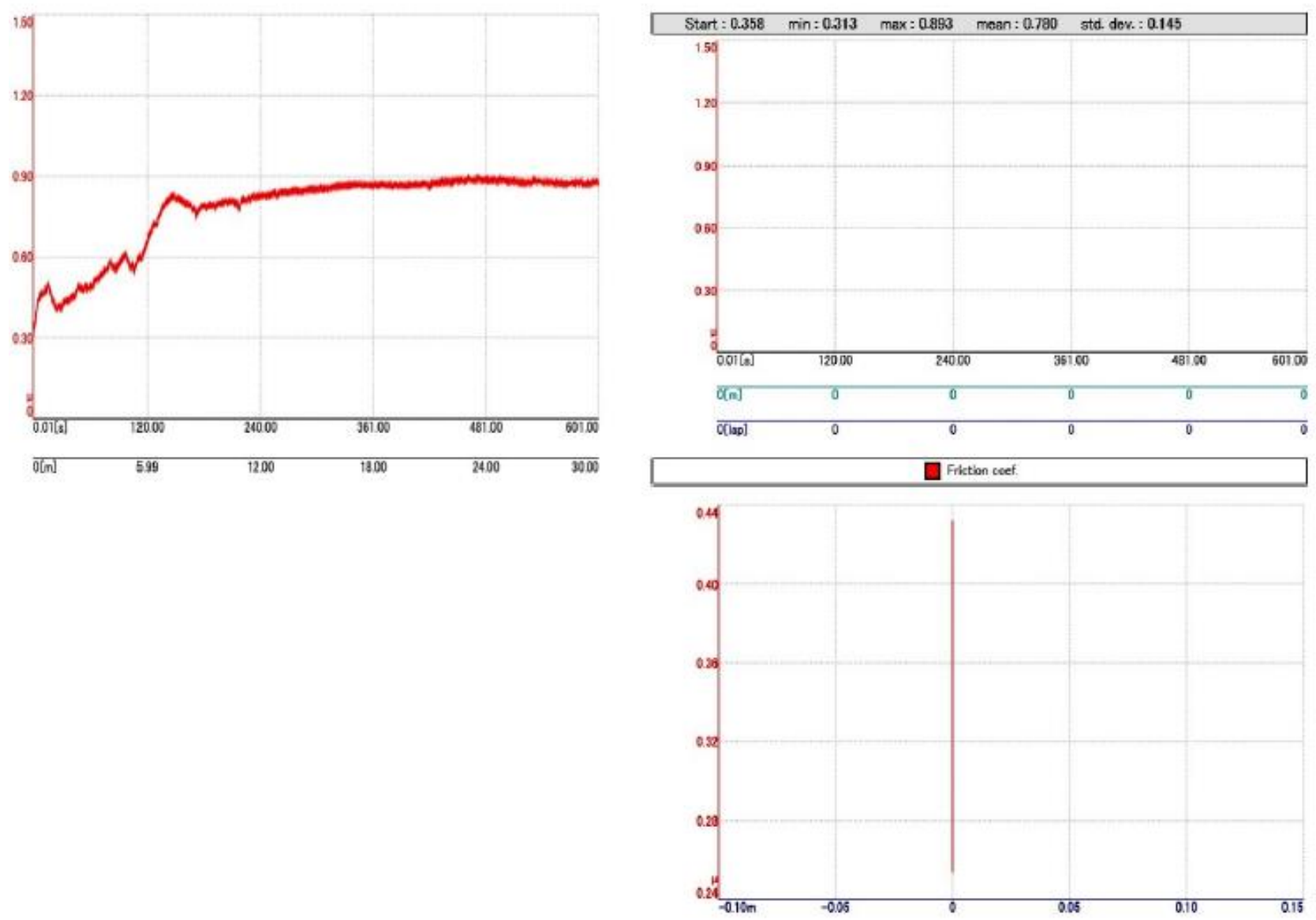

Fig. 5. Variation of the dynamic friction coefficient according to the distance travelled for $40 \mathrm{Cr} 130$ quenched from $1040{ }^{\circ} \mathrm{C}$, tempered at $150{ }^{\circ} \mathrm{C}$ and nitrided at $520^{\circ} \mathrm{C}$. 

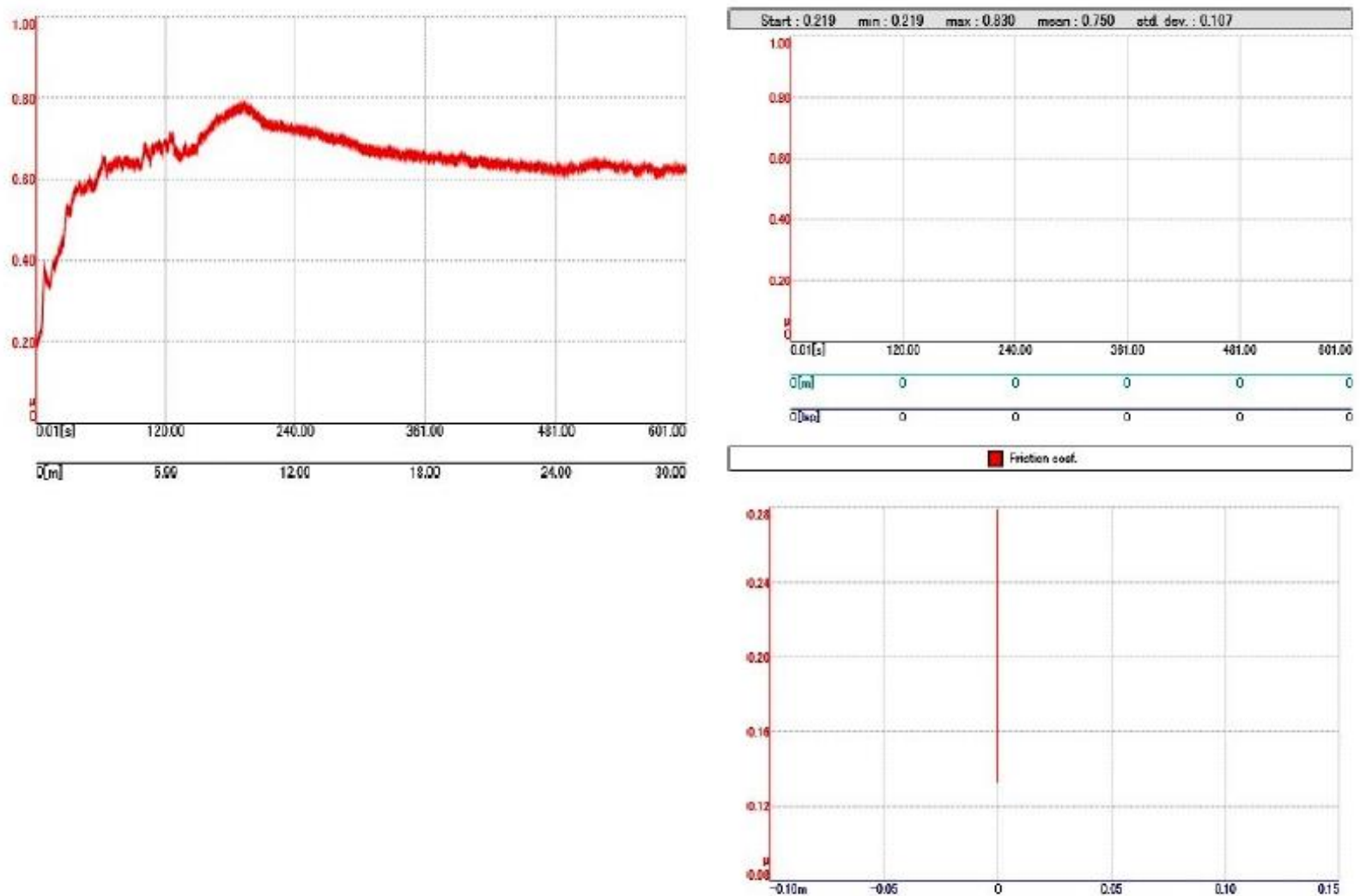

Fig. 6. Variation of the dynamic friction coefficient according to the distance travelled for $40 \mathrm{Cr} 130$ quenched from $1040{ }^{\circ} \mathrm{C}$, tempered at $510{ }^{\circ} \mathrm{C}$ and nitrided at $520^{\circ} \mathrm{C}$.

\section{Conclusions}

The thermochemical nitriding treatment leads in all cases to the improvement of the wear behaviour of $40 \mathrm{Cr} 130$, by decreasing the average values of the wear coefficient by $20-30 \%$.

Experimental research has shown the influence of austenitisation temperature on the value of the $\mathrm{K}$ coefficient. An increase in this temperature leads to a decrease in this indicator by approximately $50 \%$.

There was also possible to highlight the influence of the tempering temperature after quenching. Lower tempering temperatures in correlation with the quenching parameters lead to a decrease in the coefficient $\mathrm{K}$, except for the temperature of $1040^{\circ} \mathrm{C}$ at which it increases.

The researches show the significant importance of the heat and thermochemical treatment parameters on the behaviour in operation of high chromium alloy steels, of the 40Cr130 type; the data obtained is a useful indicator for the application of optimal technologies according to practical needs.

\section{References}

1. Geru N., et al. (1991): Analiza structurii materialelor metalice (Structure analysis of metallic materials). EdituraTehnică, ISBN 9733102822, Romania (in Romanian)

2. Giacomelli I, Druga L., Samoila C., Bot D. (2000): Tehnologii neconvenționale cu transformari de fază (Unconventional technologies with phase transformations). Editura Lux Libris, ISBN 9739428115, Romania (in Romanian)

3. Popescu N., Gheorghe C., Popescu O. (1990): Tratamente termice neconventionale (Unconventional heat treatment). Editura Tehnică, ISBN 9733101826, Romania (in Romanian)

4. Li S., Xiao M., Ye G., Zhao K., Yang M. (2018): Effects of deep cryogenic treatment on microstructural evolution and alloy phases precipitation of a new low carbon martensitic stainless bearing steel during aging. Materials Science and Engineering: A, ISSN 0921-5093, Vol. 732, pp. 167-177, https://doi.org/10.1016/j.msea.2018.07.012

5. Prieto G., Perez Ipiña J.E., Tuckart W.R. (2014): Cryogenic treatments on AISI 420 stainless steel: Microstructure and mechanical properties. Materials Science and Engineering: A, ISSN 0921-5093, Vol. 605, pp. 236-243, https://doi.org/10.1016/i.msea.2014.03.059 